\title{
Regional climate sensitivity of wetland environments in Rwanda: the need for a location-specific approach
}

\author{
Elias Nyandwi ${ }^{1,2} \cdot$ Tom Veldkamp ${ }^{1} \cdot$ Sherif Amer $^{1}$
}

Received: 14 August 2015/Accepted: 19 November 2015/Published online: 19 December 2015

(C) The Author(s) 2015. This article is published with open access at Springerlink.com

\begin{abstract}
Wetlands are sustaining large communities of people in Rwanda where $10 \%$ of its land surface consists of many local wetlands. Sustainable future management of these numerous wetlands requires a reliable inventory of their location and a dynamic quantitative characterization that allows assessment of their climate change sensitivity. The aim of this study was to assess the importance of climatic factors for determining wetland location at different regional scales. Wetland locations were analyzed and statistically modeled using their location factors with logistic regression. Wetland location probability was determined using topographic (elevation, slope), hydrological (contributing area) and climatic (temperature and rainfall) location factors. A wetland location probability map was made that demonstrated a calibration accuracy of $87.9 \%$ correct at national level compared to an existing inventory, displaying even better fits at subnational level (reaching up to $98 \%$ correct). A validation accuracy of $86.2 \%$ was obtained using an
\end{abstract}

Editor: Ülo Mander.

Electronic supplementary material The online version of this article (doi:10.1007/s10113-015-0905-z) contains supplementary material, which is available to authorized users.

Tom Veldkamp

a.veldkamp@utwente.nl

Elias Nyandwi

e.nyandwi@utwente.nl; E.nyandwi@ur.ac.rw

Sherif Amer

s.amer@utwente.nl

1 Faculty of Geo-Information Science and Earth Observation (ITC), University of Twente, P.O. Box 217,

7500 AE Enschede, The Netherlands

2 Centre for Geographic Information Systems and Remote Sensing, University of Rwanda, P.O. Box 212, Huye, Rwanda independently collected dataset. A sensitivity analysis was applied to the threshold values used as cutoff value between wetland/non-wetland, demonstrating a robust performance. The developed models were used in a sensitivity scenario analysis to assess future wetland location probability to changes in temperature and rainfall. In particular, wetlands in the central regions of Rwanda demonstrate a high sensitivity to changes in temperature $(1 \%$ increase causes a net probable wetland area decline by $12.4 \%)$ and rainfall $(+1 \%$ causes a net increase by $1.6 \%$ ). This potentially significant impact on wetland number and location probability indicates that climate-sensitive future planning of wetland use is required in Rwanda.

Keywords Wetland management · Topography · Climate change $\cdot$ Spatial scales $\cdot$ Probability model

\section{Introduction}

Wetland environments encompass the transitional zone between land and water where the land is covered by shallow water or with a water table at or near the surface (Cowardin et al. 1979). Alternatively, wetlands are defined as spatial units having ecosystems associated with long-term inundation of the soil (Keddy 2010). This latter description emphasizes the eco-hydrological and geomorphological characteristics of wetlands. Consequently, various researchers have developed wetland modeling approaches on the basis of hydrological and geomorphic characteristics (Albert et al. 2005; Brinson 1993; Large and Petts 1996; Xie et al. 2011). To a lesser extent, wetlands have characterized on the basis of topographic, hydrological as well as climatic factors (Mendoza-Sanchez et al. 2013; Ralph and Hesse 2010). Although these three components can be identified 
separately, it is apparent that there is a considerable interdependency between them. The link between water availability and local hydrodynamics becomes more enlightened when contributing area (CA) or ecological factors are considered too (Curie et al. 2007; Zhou et al. 2008).

In Rwanda, wetlands are recognized as an important natural resource and explicitly considered in national planning and policy. In 2008, the Rwanda Environmental Management Authority conducted a national inventory and mapping of all wetlands, lakes and rivers (REMA 2008). The delineation and classification accuracy of the inventory, however, were quickly questioned as numerous inconsistencies were identified during the nationwide land registration process that started 2 years later. These inconsistencies point to the fact that wetland bodies are changeable over time. During 'wetter' years, more wetland will exist than during 'drier' years. Human interventions such as artificial drainage or dam constructions will also affect wetland locations and size. A reliable demarcation of wetland in Rwanda is needed since rapid conversions change a lot on bio-physical and hydrological conditions (Hansen et al. 2009). Given the dynamic properties of wetlands, a probability approach instead of a static delineation (mapping) approach is considered more appropriate and flexible for future sustainable development.

Up to now, modeling approaches to characterize wetlands are generally based upon slope (wetlands tend to have flat slopes) and water accumulation derived on the basis of contributing area (Buis and Veldkamp 2008). Digital elevation models (DEM) are readily accessible nowadays, and automated procedures exist to compute terrain derivatives (slope, curvature, topographic index, variance in slope, etc.) which can discern real depression features from spurious ones (Hogg and Todd 2007; Temme et al. 2006; Yamazaki et al. 2012).

Less commonly used for wetland modeling are the more dynamic climate-related data that determine water availability and the local net water balance. Net water availability is a function of rainfall and evapotranspiration in the wetland catchment and the wetland itself. Evapotranspiration, in turn, is a function of vegetation, temperature and humidity.

In short, improved modeling of wetlands and their spatial and temporal dynamics requires the use of topographic, hydrological and climate variables (Adam et al. 2010). An essential advantage of such a modeling approach lies in its capability to determine how climate changes can affect wetlands in a spatially disaggregated manner.

It is therefore the objective of this paper to characterize Rwanda's wetlands in a dynamic spatially explicit way that also allows a climate sensitivity assessment. As argued above, a probability approach is followed in order to allow quantification of wetland probability in space and time. Previous investigations have demonstrated that the spatial scale (grain and extent) of analysis and management (Fóti et al. 2014; Kok and Veldkamp 2011; Veldkamp and Fresco 1997) can affect outcomes of land system properties.

\section{Materials and methods}

\section{Study area}

Rwanda is a country with considerable bio-geophysical diversity, with a main gradient from the lower and drier east to higher and wetter western part of the country. Rwanda, as case study, offers the opportunity to identify the underlying factors that drive the formation of wetlands at different spatial scales.

Rwanda is located on the great East African Plateau, which includes the continental water divide between the Nile and Congo rivers. Its climate is moderated by the altitude with an annual average temperature of $19^{\circ} \mathrm{C}$ and an annual cycle of four seasons: short rainy season, short dry season, long rainy season and long dry season (Prioul and Sirven 1981). The highland passes in a north-south direction through the western part of the country. To the west of the divide, the land drops abruptly to Lake Kivu in the Great Rift Valley. To the east, elevation gradually declines from the central plateau to the lowland of the eastern border of the country (Fig. 1), with the following natural units:

1. Ten agroecological zones (AEZ): Buberuka Highlands (BH), Bugarama Plain (BP), Central Plateau (CP), Congo Nile Watershed Divide (CNWD), Cyangugu backside (CB), Eastern Ridge and Plateau (ERP), eastern savanna (ES), Kivu lakeside (KS), Mayaga Plateau and Central Bugesera (MPB) and volcanic summits and high plains (VHP).

2. Two main major drainage basins: the Nile basin in the east covering $67 \%$ of the country and the Congo basin in the west which covers the remaining $33 \%$ (REMA 2008). The two drainage basins are subdivided into ten watersheds: Akagera (NAKA), Akanyaru (NAKU), Kivu (CKIV), Mukungwa (NMUK), Mulindi (NMUL), Muvumba (NMUV), Mwogo (NMWO), Nyabarongo amont (NNYT), Nyabarongo aval (NNYL) and Rusizi (CRUS).

\section{Potential geophysical location factors for wetlands in Rwanda}

\section{Topographic factors}

The Rwanda National Land Use and Development Master Plan Project produced a high-quality DEM with a $10 \mathrm{~m} \times 10 \mathrm{~m}$ raster cell size for Rwanda (Swedesurvey 


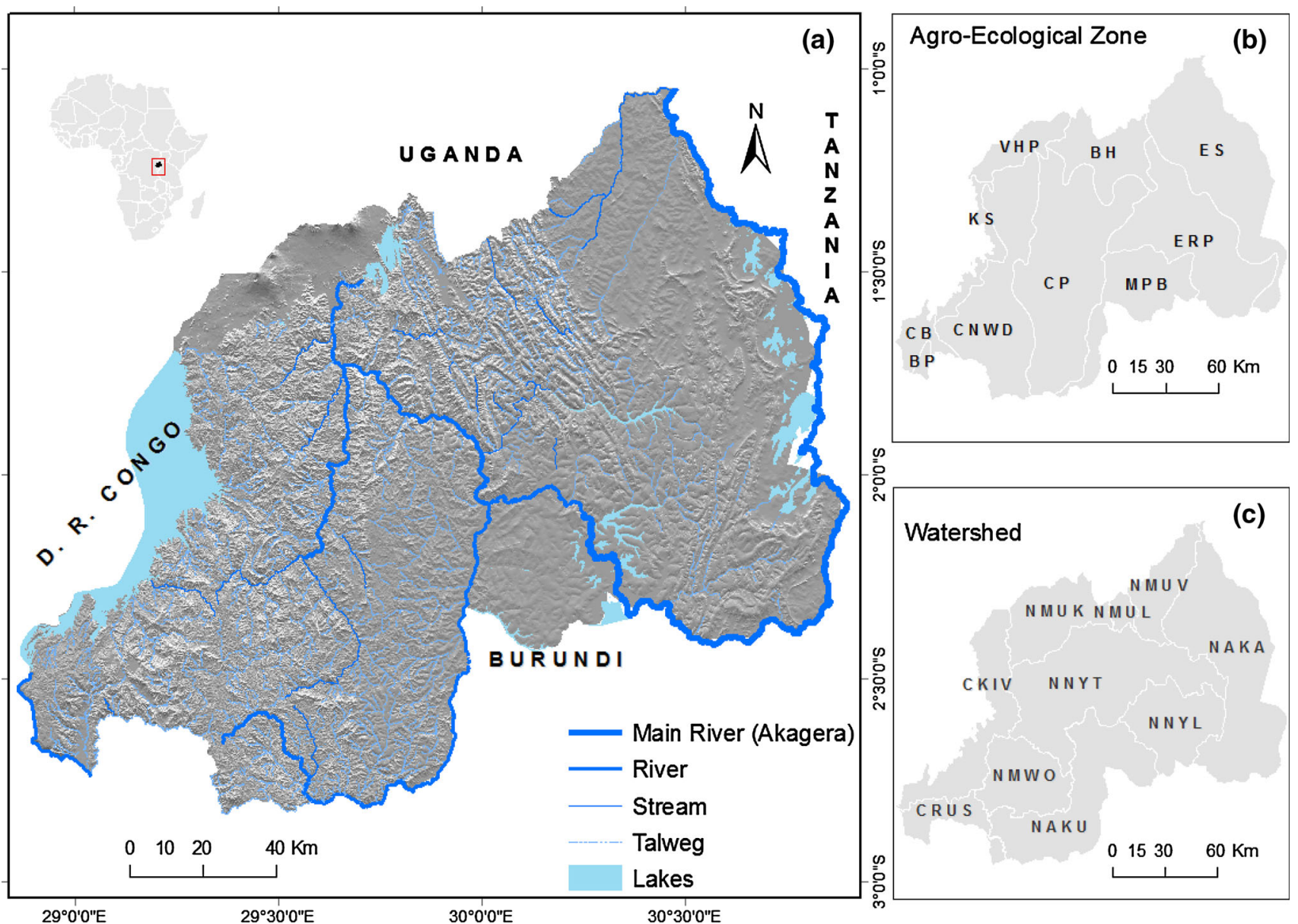

Fig. 1 Inland lakes and hydrological network Rwanda with Akagera as main river, collecting water from $67 \%$ of the country into the Nile River Basin (a). The delimitation of regions used in subnational

2010). From the DEM, a point grid was extracted with an interval of $10 \mathrm{~m}$. The DEM was provided by the Rwanda Natural Resources Authority for this study.

In addition to elevation data, the DEM was used to derive the slope gradient which is used as a landform characteristic in this study. The slope gradient data set, which indicates the rate of maximum change in elevation for each cell of the DEM, was calculated using the following (Eq. 1):

Slope $(\%)=100$. Sqrt $\left(\left(\mathrm{d} x^{2}+\mathrm{d} y^{2}\right) /(2 \times \text { grid size })^{2}\right)$

where $\mathrm{d} x$ height difference (m) of the pixel in $x$ direction and $\mathrm{d} y$ height difference $(\mathrm{m})$ of the pixel in $y$ direction, and grid size is the length of the side of one grid that assume the length for each side is the same.

A second topographic derivative that was extracted from the DEM is the contributing area (CA), which represents a hydrological characteristic. The CA dataset was generated using LandscApe ProcesS modeling at mUlti-dimensions and Scales (LAPSUS) techniques, as this resolves the issue modeling is visualized by two maps in right corner, namely ten agroecological zones (b) and ten main watersheds (c)

of divergent flows and multiple depressions (Temme et al. 2006).

\section{Climate factors}

A network of 183 meteorological stations (see Fig. 2a) distributed throughout the country records rainfall, temperature, evapotranspiration and relative humidity. Annual averages of these data were measured for most stations using 60-year records starting from 1950 to 2010 and obtained from the Rwanda Meteorological Center. We interpolated these data using the thin-plate smoothing spline algorithm as proposed by Hijmans et al. (2005). The produced maps were transferred to raster datasets with a 10-m cell size following the approach of Mukashema et al. (2014).

\section{Wetland, agroecological zone and watershed data}

In addition to above-described factors data, several additional GIS and remotely sensed data sets were used. For 
Fig. 2 Location of a 183 Rwandan (agro) meteorological station and $\mathbf{b}$ Field dataset sampling sites overlapped to Rwandan Wetlands as defined by the inventory and mapping of wetland by REMA (2008)

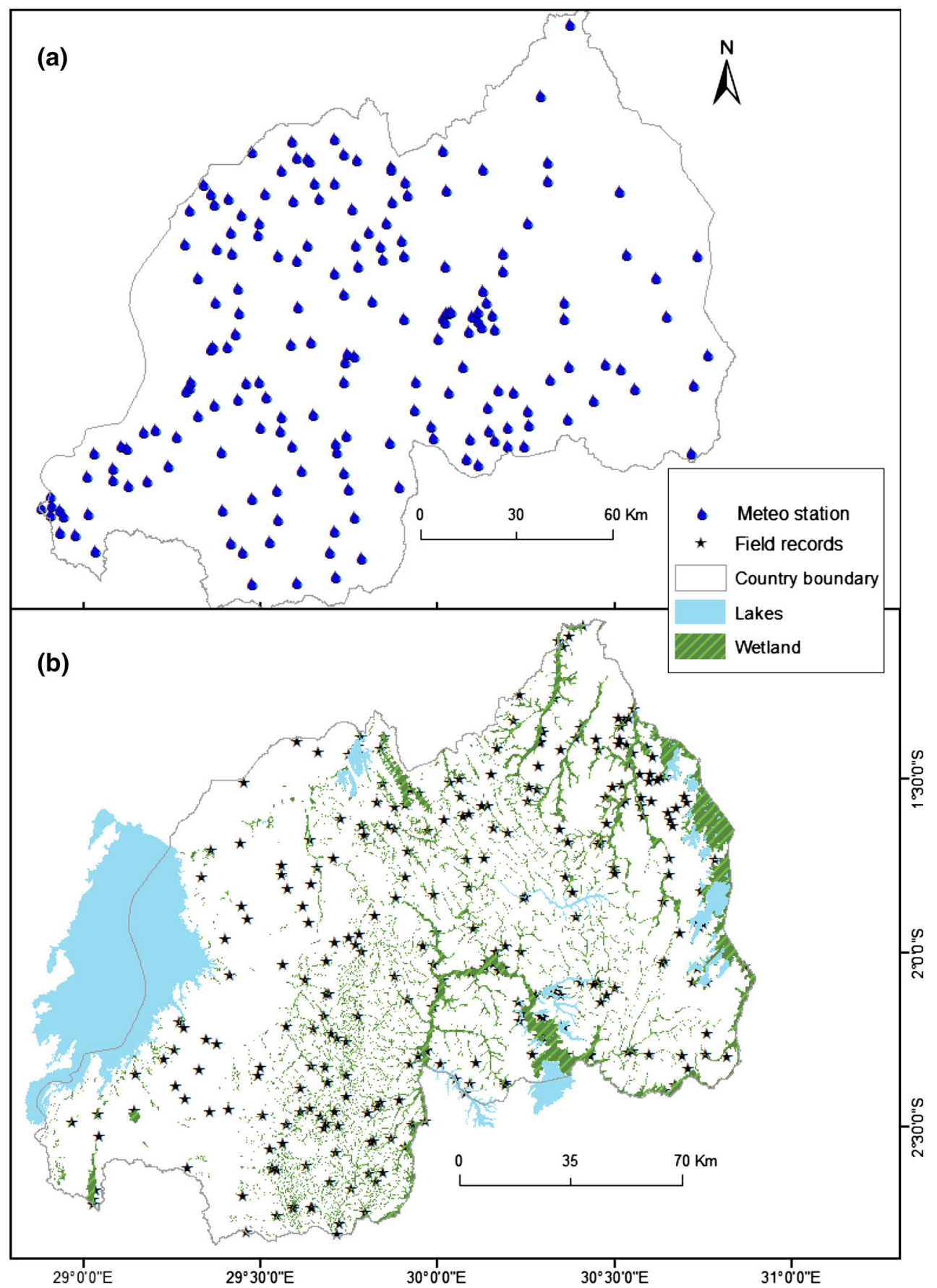

wetland/upland sampling, wetlands, lakes and country boundary data were used. The wetland data used originate from the inventory conducted in 2008 by REMA, which produced 860 wetlands covering a total surface of 278,536 ha, corresponding to $10.6 \%$ of total country area. The administrative boundary of Rwanda, agroecological zone boundaries (defined on the basis of altitude, rainfall and soil characteristics) and main watershed boundaries were obtained from the Centre of GIS and Remote Sensing of the University of Rwanda. In addition, field data were collected at 299 locations (see Fig. 2b), randomly spread over the country during March-July 2013 and DecemberApril 2014. For each geographic location, the X, Y coordinates of site categorized as wetland/upland were recorded. The empirical data generated from field work are used for independent validation of the statistical models. 


\section{Data preprocessing and processing}

\section{Data preparation}

In this study, we limit ourselves as much as possible to the use of original measured data. The rationale for this is to avoid data redundancy, between derivatives that share the same data source. A terrain derivative such as the topographic index, which is frequently used in simpler models that do not consider hydrological data (Chirico et al. 2005), is therefore not included in the analysis. Evapotranspiration and relative humidity are highly correlated with (often calculated using) temperature and rainfall and therefore also excluded from the analysis (Creed et al. 2003; Hogg and Todd 2007). The most important and independent topographic and climatic factors to predict the occurrence of wetlands in Rwanda are summarized in Table 1a.

To correspond with the spatial resolution of the DEM, all factor raster data were resampled a $10-\mathrm{m}$ cell size. Another motive for choosing a high spatial resolution is to also capture smaller-sized wetlands of which there are many in Rwanda. Factor data were subsequently standardized into a range from 0 to 1 using a minimum-maximum linear transformation. This normalization is necessary to ensure comparison of values of the same range, which is an important prerequisite for multiple variable analysis with continuous variables (Long et al. 2010).
Sampling design

Training sample points were randomly selected from wetland and non-wetland locations. To prevent spatial autocorrelation, data points were sampled from the REMA map of wetland for training (50\%) and validation $(20 \%)$ purposes, respectively. Wetland polygons were merged to allow random distribution of points to be generated from total coverage. The non-wetland area was identified using ArcGIS overlay functionality by excluding all wetlands and water bodies. The sampled point dataset with 1 single attribute $(0=$ non-wetland, $1=$ wetland $)$ was further populated by extracting the associated elevation, slope, contributing area, rainfall and temperature values from the respective factor raster data. The fully populated attribute table was then exported and analyzed using SPSS Statistics 20.

The same process was repeated for each agroecological zone and for each watershed.

\section{Logistic regression analysis (LRM)}

Given that our dependent variable is dichotomous (either wetland or no wetland) and we have a set of predictor variables, a binary logistic regression approach is a suitable statistical technique for our analysis (Burns and Burns 2009). Binary logistic regression determines the impact of multiple independent predictor variables presented

Table 1 (a) The most original factors used for wetland occurrence modeling, (b) predicting factors of wetlands occurrence and their statistical coefficients

\begin{tabular}{|c|c|c|c|c|c|}
\hline Category & Factors & \multicolumn{4}{|l|}{ Description } \\
\hline \multicolumn{6}{|l|}{ (a) } \\
\hline \multirow[t]{3}{*}{ Topographic } & Elevation & \multicolumn{4}{|c|}{ Preprocessed high-resolution DEM of 10-m cell size produced using ortho-photographs, 2008} \\
\hline & Slope & \multicolumn{4}{|c|}{ Slope calculated using DEM } \\
\hline & $\begin{array}{l}\text { Contributing } \\
\text { area }\end{array}$ & \multicolumn{4}{|c|}{ Hydrological modeling-multiple flow accumulation using LAPSUS Model } \\
\hline \multirow[t]{2}{*}{ Climatic } & Rainfall & \multicolumn{4}{|c|}{$\begin{array}{l}\text { Total rainfall in mm measured at meteorological station, interpolated to obtain values for the whole study } \\
\text { area }\end{array}$} \\
\hline & Temperature & \multicolumn{4}{|c|}{ The annual mean measured at meteorological station, interpolated to obtain values for the whole study area } \\
\hline \multicolumn{2}{|l|}{ Parameters } & $B$ & SE & Wald & $\operatorname{Exp}(B)$ \\
\hline \multicolumn{6}{|l|}{ (b) } \\
\hline \multicolumn{2}{|l|}{ Elevation } & -0.008 & 0.001 & 65.136 & 0.992 \\
\hline \multicolumn{2}{|l|}{ Slope } & -0.213 & 0.020 & 108.038 & 0.808 \\
\hline \multicolumn{2}{|c|}{ Contributing area } & 0.001 & 0.001 & 28.060 & 1.000 \\
\hline \multicolumn{2}{|l|}{ Rainfall } & 0.002 & 0.001 & 11.475 & 1.002 \\
\hline \multicolumn{2}{|l|}{ Temperature } & -0.815 & 0.159 & 42.096 & 0.357 \\
\hline \multicolumn{2}{|l|}{ Constant } & 30.650 & 4.395 & 48.625 & $2.047 \mathrm{E}+13$ \\
\hline
\end{tabular}


simultaneously to predict membership of one or other of the two dependent variable categories (Ravi and Kulasekaran 2013). The typical link purpose is logit function, which in this case related the logarithm of the odds ratio of expected value of wetland probability to linear covariant of elevation (Elev), slope (Slp), collecting area (CA), temperature (Temp) and rainfall (Rain). If the $[\pi(x)]$ represent the expected value of probability of wetland occurrence at location $i$, then the logistic regression model is (Eq. 2):

$$
\begin{aligned}
\text { Logit }\left[\pi(x)_{i}\right]= & \beta_{0}+\beta_{1} \times \operatorname{Elev}_{i}+\beta_{2} \times \operatorname{Slp}_{i}+\beta_{3} \times \mathrm{CA}_{i} \\
& +\beta_{4} \times \mathrm{Temp}_{i}+\beta_{5} \times \operatorname{Rain}_{i}
\end{aligned}
$$

where $x$ is the probability of wetland occurrence; $\beta_{0}, \beta_{1}, \beta_{2}$, $\beta_{3}, \beta_{4}$ and $\beta_{5}$ are the regression coefficients to be estimated for the independent variables.

The T-Wald statistic ( $z$-value) and associated probabilities provide an index of the significance of each predictor in the equation. The Wald statistics asymptotically follow $\chi^{2}$ distribution (Kharkar and Bowalekar 2014). Also, the $\operatorname{Exp}(B)$ (odds ratio) presents the extent to which raising the corresponding measure by one unit influences the probability of the dependent variable (Burns and Burns 2009), wetland occurrence in this case. In addition, the Nagelkerke's $R^{2}$, meaning the power of explanation of the model, was also considered.

\section{Creation of wetland probability geo-database}

The wetland probability geo-database was computed (with ArcGIS 10.1) using the coefficients of the fitted regression model for the significant predictor variables. The resulting raster map displays the probability of wetland occurrence, ranging from low probability (yellow) to high probability (dark blue).
Sensitivity of the LR model to spatial scale and climate factors

As discussed above, logistic regression analysis was done to assess whether topographic and climatic factors can reliably determine the probability of wetland occurrence. Because of the potential scale sensitivity, it was relevant to explicitly assess the influence of spatial scale on the studied system properties. In order to adequately capture such potential scale effects, the wetland characterization of Rwanda was done at two different spatial scales. In first instance, the analysis was done at national level for Rwanda as a whole. After the national extent, the analysis was repeated at subnational level using the same predictors but now in a spatially disaggregated manner for each individual agroecological zone and watershed, respectively.

Differences in model performance at national and subnational scale were compared to assess whether model fits are indeed sensitive to spatial extent. The subnational model results were subsequently reassembled to produce a new composite probability geo-database for the country as a whole (Fig. 3).

To illustrate how climate change can impact on spatial wetland occurrence, a scenario with an overall increase of $1 \%$ for temperature and rainfall, respectively, was calculated with the developed logic regression models. The slight increase of $1 \%$ was selected referring to the trend analysis of the annual mean temperature in Rwanda during last 52 years (Safari 2012). New wetland probability maps were calculated and compared. In the two scenario's cells, a probability value used as threshold was defined after the sensitivity analysis of the probability map of wetland occurrence produced using logistic regression models. Different thresholds for different scale and models were expected. (a)

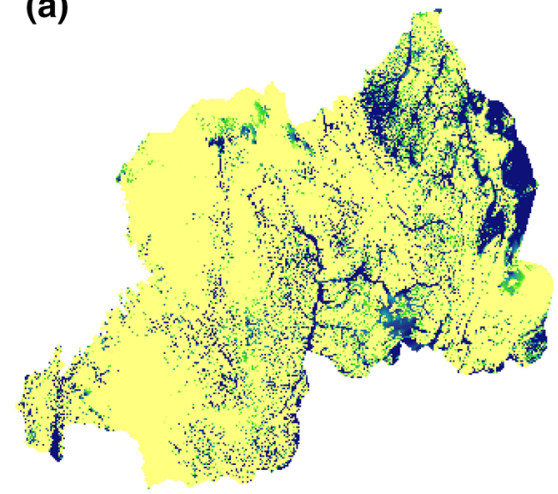

(b)

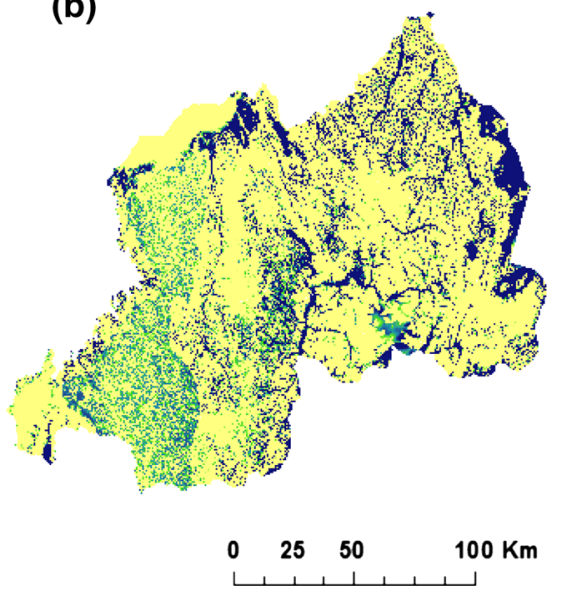

(c)

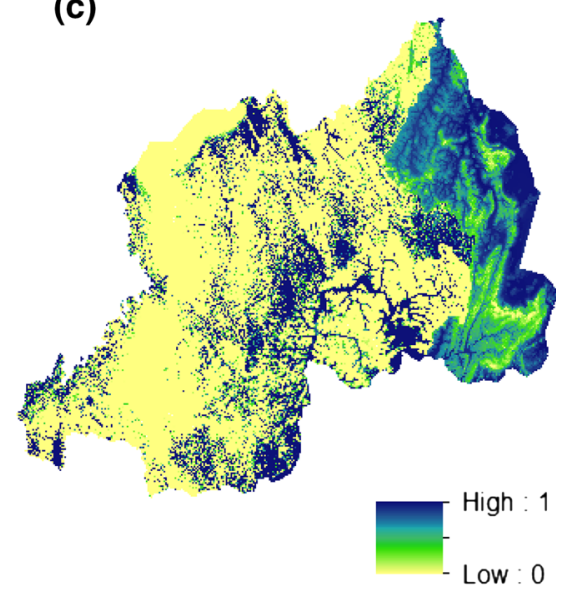

Fig. 3 Wetland probability map generated using logistic regression model at national level (a), composite probability map with AEZ models (b) and composite probability map with watershed models (c) 


\section{Model performance and validation}

In addition to statistical significance testing, the performance of the model was independently assessed using the field-based data set, collected at 299 randomly selected wetland and upland sites. The location of ground-based dataset of wetland/upland as points map is provided with Fig. 2.

In this case, we also made a sensitivity analysis for testing the robustness of the results of our models at national and regional level using XY scatter plot of different probability values from 0.6 to 1 .

\section{Results}

\section{Predictors of wetland occurrence at national level}

A test of the full model against a constant only model is statistically significant, indicating that the predictors together can significantly distinguish between wetland and nonwetland locations $\left(\chi^{2}=547.271, p<0.000\right.$ with $\left.d f=5\right)$. Also, the classification error rate changes from $50 \%$ (Step 0 ); by adding the variables, we can now predict with $85.0 \%$ overall accuracy $(87.9 \%$ for wetland and $82.1 \%$ for non-wetland). Nagelkerke's $R^{2}$ of 0.628 .

The national model has elevation, slope, rainfall, temperature and contributing area as significant independent factors considering the Wald's test. The strong contribution of single variable expressed by the $\operatorname{Exp}(B)$ coefficient is attributed to both topographic (slope) and climatic (temperature) factors as summarized in Table $1 b$.

\section{Spatial scale dependence}

\section{Agroecological zone level}

The analysis at agroecological zone level results in ten logistic regression models, each with its own coefficients. Table A (Electronic Supplemental Material) summarizes the significant drivers of wetland occurrence for each agroecological zone.

For Mayaga Plateau and Central Bugesera (MPB), all five potential predictor variables are included in the fitted model. The odd ratios clearly indicate that slope and temperature are the most forcing factors predicting wetland occurrence.

In the agroecological zones of Buberuka Highland (BH) and Bugarama Plain (BP), elevation, temperature and slope are the main factors predicting wetlands. As can been seen in Fig. 1, BH is characterized by rather abrupt altitude and therefore temperature change. In the Bugarama Plain, located in the southwestern and lowest part of the country, temperature and slope are the most important predictors.

For the Central Plateau (CP), with its dense drainage network, the main predicting factor is temperature. Slope and elevation have only minor influence; rainfall is not a significant factor.

The Congo Nile Watershed Divide (CNWD), Cyangugu backside (CB), Eastern Ridge and Plateau (ERP) and Kivu lakeside (KS) all have topographically sensitive wetlands. Slope, elevation and contributing area are, respectively, the best predicting factors.

In the eastern savanna (ES), wetland occurrence is only and strongly associated with slope.

The volcanic summits and high plains (VHP) model also represents an exception by not including 'elevation' but instead introducing 'rainfall' as a predictor for wetlands occurrence.

Temperature is a highly significant climate predictor in the Buberuka highland, Bugarama Plain, Central Plateau, Mayaga Plateau and Central Bugesera and Eastern Ridge and Plateaus. Rainfall predicts wetland occurrence with moderate significance in the volcanic summits and high plain zone.

Model fit improved with an increase in Nagelkerke's $R^{2}$ from 0.628 to 0.910 , and the prediction success improved with overall accuracies ranging from 0.85 to 0.98 for seven out of ten AEZ. Model performance decreased in the Central plateau and the Cyangugu backside (from 0.628 to 0.524 with overall accuracy of classification decreased to $81.7 \%$ ). In general, an increase indicates that wetland that is better captured by the regional models than the model at national level (Kok and Veldkamp 2011).

\section{Watershed level}

At the level of watersheds, the regional models also performed differently in comparison with the national model, as summarized by Table B (Electronic Supplemental Material).

Wetlands in the Akagera watershed are predicted by elevation, slope and rainfall with a highly significant effect of slope. The Akanyaru watershed retains the same predictors as the national model, but with improved statistical performance.

For the Mukungwa catchment, elevation and temperature are not included in the model as explanatory factors. For the Mulindi and Rusizi watersheds, both temperature and contributing area are insignificant. The most significant factors for these watersheds are, respectively, slope, elevation and rainfall. In Muvumba watershed, wetlands characteristics can be explained by elevation, slope, contributing area and rainfall. 

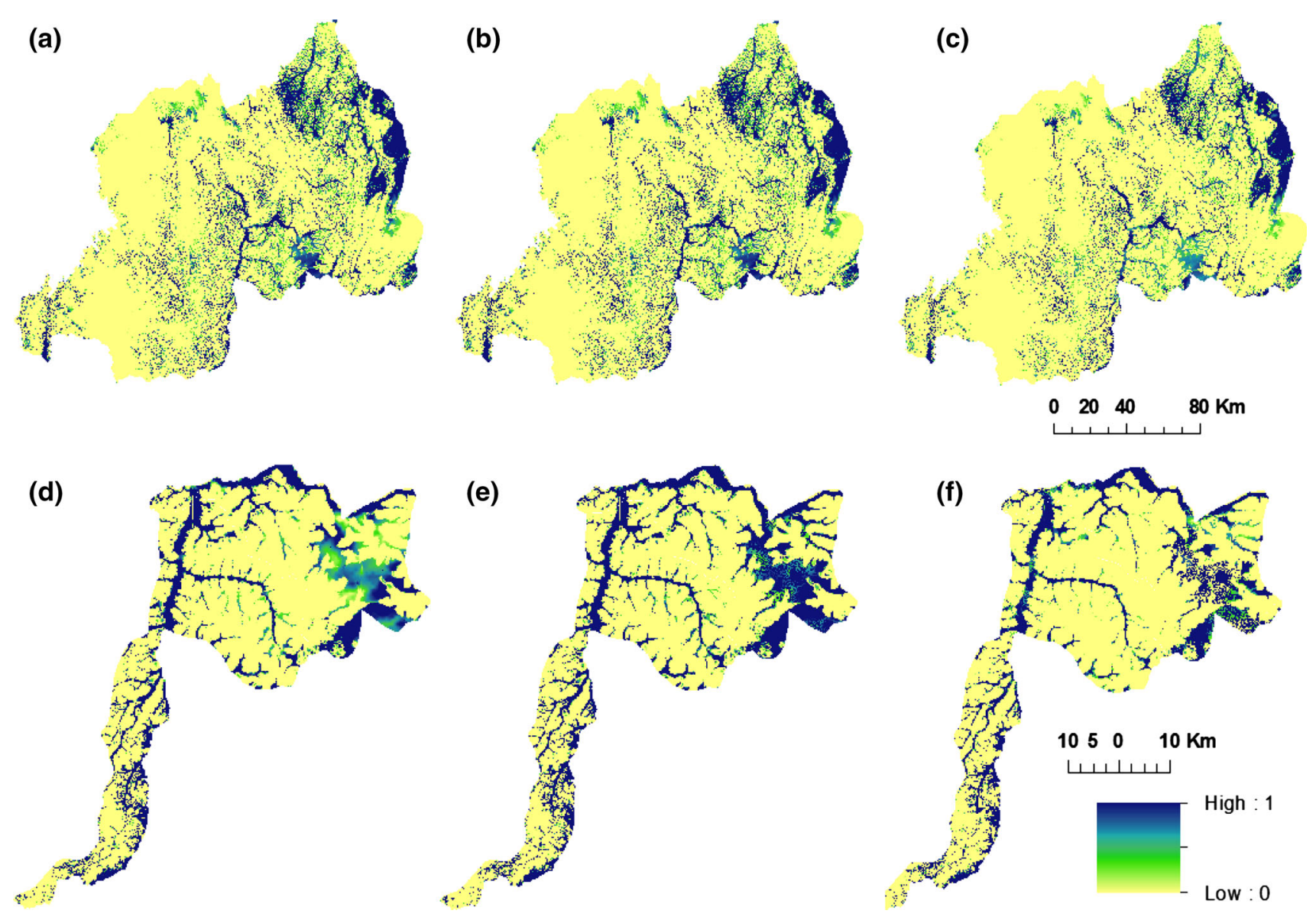

Fig. 4 Wetland sensitivity to climate changes maps at national level: created with current climate factors value (a), with $1 \%$ increase in rainfall (b) and with $1 \%$ increase in temperature (c). Sensitivity maps

at the most sensitive agroecological zone of MPB created using current climate factors value (d), with $1 \%$ increase in rainfall (e), with $1 \%$ increase in temperature (f)

In Nyabarongo amont and Nyabarongo aval, elevation, slope and temperature predict wetlands occurrence with temperature as the most contributing predictor.

Overall, both topographic and climatic components are equally important in predicting wetland occurrence at watershed level, with a minimum of three drivers per model. The rainfall was included in the model for most watersheds as significant contributing factor.

Considering the Nagelkerke's $R^{2}$ and overall accuracy, three different outcomes can be noticed with respect to model outputs: (1) In some watersheds, the model performance is more or less equal to the national level namely Akagera, Kivu, Nyabarongo amont and Mwogo catchments; (2) the subnational models performed not very well in the Muvumba and Akanyaru catchments; and (3) in four cases (Mulindi, Nyabarongo aval, Mukungwa and Rusizi), the catchment model performed much better reaching $90 \%$ and higher.

A visual inspection of the wetland probability maps at national, agroecological zone and watershed level shown in Fig. 4 reflects: (a) quite similar probability for national and

watershed-based models in the northern and western part of the country; (b) changing probabilities with all models in south and central part of the country and (c) a more wet eastern part of the country (i.e., the Akagera watershed).

\section{Exploring climate sensitivity of Rwandan wetlands}

The sensitivity scenario of a $1 \%$ increase in, respectively, rainfall and temperature results in considerable changes in the spatial pattern and dimension of wetland probabilities. An increase in rainfall is expected to lead to more/larger wetlands, whereas an increase in temperature will lead to more evapotranspiration and therefore result in a reduction in wetlands. The accuracy of the threshold probability values was tested independently by a reliability analysis and will be discussed later.

Table C (Electronic Supplemental Material) summarizes how a $1 \%$ increase in rainfall or temperature will affect the extent of wetlands. If we use the national model, a $1 \%$ overall increase in rainfall will result in an overall growth of $1.6 \%$ of wetland area (using a threshold probability of 
0.6). A $1 \%$ increase in temperature will have a considerably stronger impact and results in a nationwide decline of $12.4 \%$ of probable wetland area. To determine the effects of climate change at a spatially disaggregate level, Table C (Electronic Supplemental Material) also presents a comparison at agroecological zone using Mayaga Plateau and Central Bugesera as an example. In this case, we see that a $1 \%$ increase in rainfall will result in an expansion of probable wetland area of $16.2 \%$. A $1 \%$ increase in temperature in Mayaga Plateau and Central Bugesera will have a very substantial impact as it will reduce probable wetland area by as much as $37.9 \%$.

More in general, the above examples demonstrate that the impacts of climate change will vary considerably from place to place. It also underlines the importance of using spatially disaggregate models as these are capable of identifying in which locations climate change will have more effect. The scenarios, also illustrated by Fig. 4, clearly demonstrate the location-specific regional sensitivity of climate change on wetland probability in Rwanda.

\section{Wetland prediction models sensitivity analysis and accuracy assessment}

A reliability analysis was complemented by using an independent dataset collected from field. The results are summarized in Table D (Electronic Supplemental Material). The topographic and climatic factors used in the best fitting statistical and spatial model explained $86.2 \%$ of the probability of wetland conditions to occur. The number of field observations was not sufficient to conduct a similar validation exercise at each AEZ and watershed.

The sensitivity analysis of the used thresholds for wetland-non-wetland distinction was done by testing the robustness of the results of our models at national and regional level. The $85 \%$ of correct classification of wetland occurrence was reached with probability value of 0.6 . Wetland occurrence probability reaching $95 \%$ of accuracy/confidence as the target is reachable with a threshold of 0.6 of probability for national model. The AEZ and watersheds wetland occurrence probability map need to use mostly 0.7 and in few cases 0.8 for probability maps with right visualization as illustrated by XY scatter plot on Fig. 5 . In general, it can be concluded that given the steepness for the cumulative graphs in Fig. 5, all thresholds are distinctive and robust in separating wetlands from non-wetlands.

\section{Discussion and conclusions}

The use of topographic (elevation and slope), hydrological (contributing area) and climatic (rainfall and temperature) factors allowed the construction of statistically significant models for wetland characterization. The models give satisfactory accuracy $(86.22 \%)$ considering the highly complex nature of wetlands in Rwanda and the limited number of variables used. The variables selected in the logistic regression models vary in number and significance [standardized betas coefficient and $\operatorname{Exp}(B)]$ at the different spatial scales used in the analysis presented. This indicates the highly regional-specific nature of Rwandan wetlands. The potentially most dynamic wetland determining factors are climate-related factors even though these are not significant for all regions. All regional models, however, contain the more static topographic factors. Clear differences in wetland characteristics and sensitivities exist between agroecological regions. When homogeneous and high spatial and temporal resolution climate data are available, the potential spatial dynamics of wetland in Rwanda can be better assessed. Such information, in turn, is highly valuable for their rational management. A onesize-fits-all management approach is clearly not going to be the most appropriate strategy for future policy development. We therefore recommend to use a location-sensitive approach, as presented in our study to identify which wetland environments require extra attention in order to make them future proof.

\section{Functional wetlands surfaces characterization drivers}

Our study demonstrates that topographic and climatic factors are suitable to predict wetland occurrence in Rwanda at a level of $86.22 \%$ accuracy. The importance of both factors was demonstrated at national and subnational levels.

Landforms are relatively stable landscape features which are dominant factors influencing the particular hydrological conditions (Hengl et al. 2003). Thus, slope and elevation appear to be consistent variables for the prediction of wetlands (Creed et al. 2003; Hogg and Todd 2007).

Climatic components, one the other hand, are more dynamic and have varying importance as wetland occurrence predictor at the different scale levels. Climate variations or change is a prime driver of the water regime in the wetland ecosystem and can be a key factor for their characterization (Zhao et al. 2011) and management. Several studies around the world revealed the importance of climate factors as hydrological contribution at wetland and full catchment level (Mendoza-Sanchez et al. 2013; Nagumo et al. 2013; Schulte et al. 2009). The varying significance of temperature can be associated with its altitudinal degradation from bottom land to the hilltop (Dai and Huang 2006; Melloh et al. 1999). For that reason, some wetland managers have already integrated climatic 

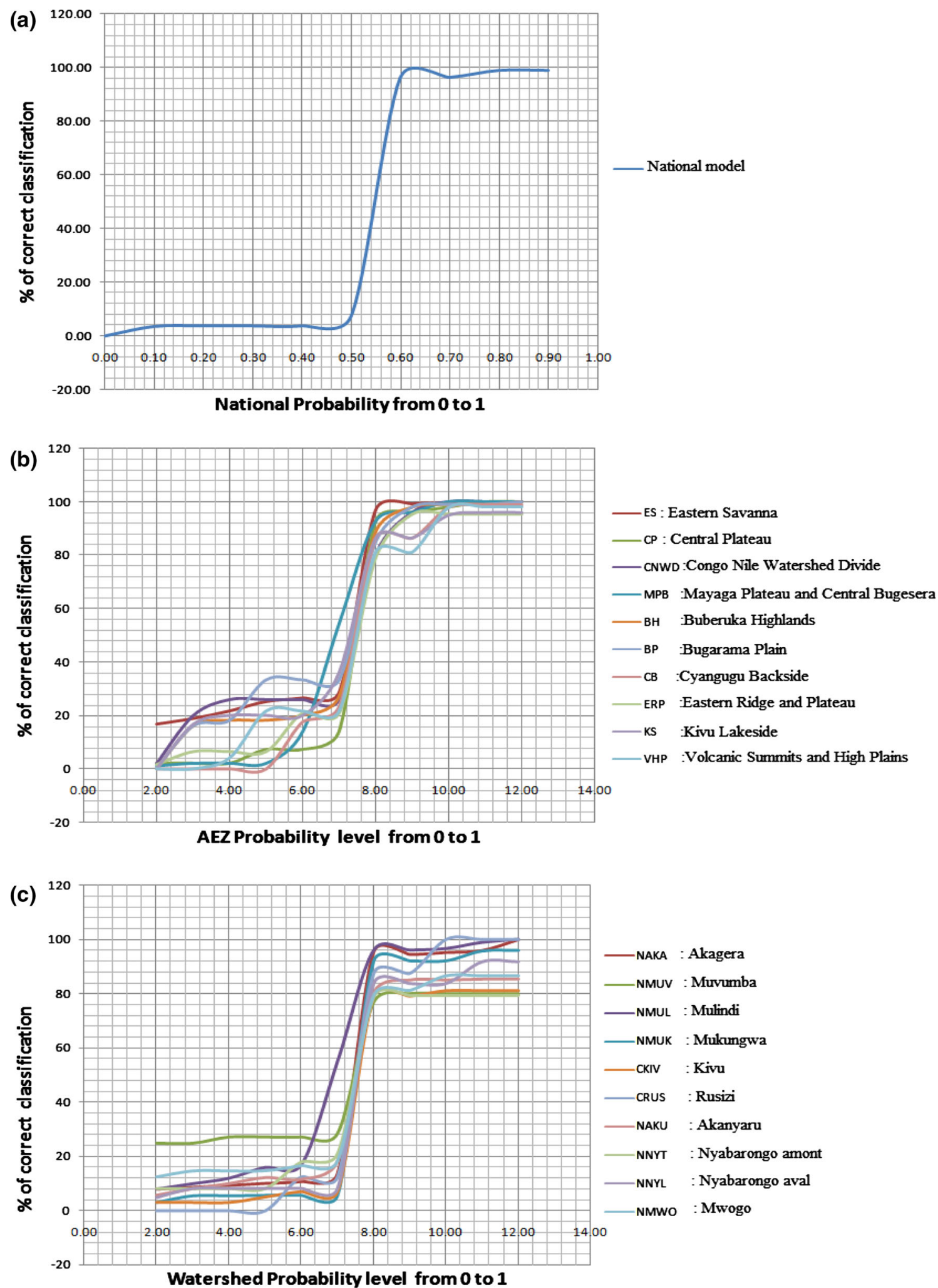

Fig. 5 Sensitivity analysis using XY scatter plot of probability value of wetland occurrence maps created using logistic regression models from national (a), AEZ to regional level, respectively, agroecological zones (b) and watershed (c) 
conditions such as rainfall and temperature for assessing wetness conditions (Dimitriou and Zacharias 2010; Gell et al. 2013).

\section{Spatial scale sensitivity}

The prediction of wetland occurrence probability at multiple spatial scales revealed variations of predicting factors and model performance.

In most cases, both climatic and topographic factors were combined in fitted models with different numbers of factors and different levels of significance. However, a few agroecological zones turned out to be exceptions as no single climatic component was included in the probability model. These are the Congo Nile Watershed Divide, the Cyangugu backside, the Kivu lakeside and the eastern savanna (Fig. 1b, c). Out analysis suggests that in these regions the wetlands are less climate sensitive as in the other regions. The agroecological zoning invokes similarities in bio-geophysical conditions and land uses activities defining characteristics of surrounding ecosystem such as wetlands (Delepierre 1982; Ndayambaje et al. 2012). The exclusion of climate variables can be explained by the fact that the structural relief has an impact on rainfall distribution and hydrological network. On the Kivu lakeside, the Cyangugu backside and the Congo Nile Watershed Divide, slope elevation and contributing area are sufficient to predict wetland. These three agroecological zones are the result of geologically recent tectonic movement (Grzybowski 1992) creating the Arbertine Rift and the mountains with sharp boundaries. Here wetlands are bottomland receiving enough water from the well-watered upland. The region is the water tower of the whole country. Secondly, the eastern savanna has relatively large swamps communicating with a series of lakes. The latter receives water from Akagera river overflow during wet season, in a hydrological connectivity mechanism as described by Karim et al. (2012) for similar case in Australia.

Our analysis shows that the central part of Rwanda, hilly with medium elevation and many small wetlands, has a potentially most climate change-sensitive wetlands. That is in line with others' studies recognizing the changing impact of drivers with variation of spatial scale of given ecosystem (de Koning et al. 1998; Kok and Veldkamp 2001).

Our study also illustrates that future-proof land use planning requires a multi-scale approach. National level land use plans that need to be refined for specific targeting of climate-sensitive wetland areas are strongly recommended.

\section{Wetlands are sensitive to climate variations}

The presented climate change scenarios demonstrate that wetlands in particular zones in Rwanda are more sensitive to climate change. This result confirms the issue of lakes/ wetlands sensitively expanding, reducing or even disappearing in some part of the country with climate variations (Nzigidahera 2007). Our study also demonstrates that not all wetlands are equally sensitive to climate change and that the more sensitive regions are found in central Rwanda.

\section{Model performance and accuracy}

Model performance is generally better at the more detailed subnational (AEZ and watershed) scale level. The models show differences between descriptive and predictive power of specific variables (Apan and Peterson 1998; Galletti et al. 2013). The overall accuracy reaching 86.22 \%-93\% with field-based dataset is a clear improvement compared to studies using topographic derivatives only. Hogg and Todd (2007) reached only $84 \%$ of accuracy in characterizing wetlands in southern Ontario using a very high-resolution DEM ( $2 \mathrm{~m} \times 2 \mathrm{~m}$ pixel size $)$ at detailed scales.

The advantage of using empirical models based on statistical analysis instead of process-based models is the case study sensitivity. Much of the local specificity is automatically incorporated by the use of local data. A main drawback is that many known system sensitivities based on known processes are not always incorporated or apparent. Process-based modeling has this capability, but usually requires very specific data (mainly discharge and evaporation data) which are not commonly available in countries like Rwanda. We therefore consider our empirical approach a first step toward understanding the wetland probability distribution directing future process-based research.

Other ways to improve functional wetland characterization may be to use higher-resolution data (now not available) and/or other data such as accurate soil information. Given the human impact on wetlands (used for agriculture and the constructions of dams of drains), the inclusion of such factors could also improve wetland occurrence characteristic.

\section{Conclusion}

The results of this study demonstrate the relevance of combining terrain derivatives and climatic factors in characterizing functional wetland occurrence in Rwanda. In line with previous studies, the Rwandese case study confirms the explanatory power of topographic attributes (elevation, contributing area and slope). Moreover, the logistic regression model demonstrates that climatic factors are also important in determining wetland occurrence probability. The importance of climatic factors varies 
across space and is more scale sensitive. The logistic regressions were able to quantify the significance of climatic conditions for wetland definition in Rwanda.

The multi-scale quantification of climate sensitivity, using different values for temperature and rainfall in the model, illustrates that wetlands in Rwanda are highly sensitive to climate changes. An increase of $1 \%$ in the national average temperature can result in a reduction of more than $12.5 \%$ of current national wetland coverage. The multi-scale approach demonstrates that the wetlands in the central part of the country are the most sensitive to climate change.

Our results underline that future wetland planning should be based upon at a multi-scale approach to ensure future-proof utilization of this important natural resource in Rwanda.

Acknowledgments This work was financially supported by Dutch Government, Nuffic Programme under the Project NICHE/RWA/071. We extend our sincere appreciation to the Rwandan Meteorological Center, Rwanda Natural Resources Authority/Land and Mapping department and Rwanda Environment Management Authority for providing, respectively, meteorological records, high-resolution digital elevation model (DEM) and official and up to date wetlands map of Rwanda. The authors acknowledge the technical assistance from Dr. Ir. Temme of Wageningen University_LAPSUS project team member, for generation of a realistic contributing area and his insightful comments.

Open Access This article is distributed under the terms of the Creative Commons Attribution 4.0 International License (http://crea tivecommons.org/licenses/by/4.0/), which permits unrestricted use, distribution, and reproduction in any medium, provided you give appropriate credit to the original author(s) and the source, provide a link to the Creative Commons license, and indicate if changes were made.

\section{References}

Adam E, Mutanga O, Rugege D (2010) Multispectral and hyperspectral remote sensing for identification and mapping of wetland vegetation: a review. Wetl Ecol Manage 18:281-296. doi:10.1007/s11273-009-9169-z

Albert DA, Wilcox DA, Ingram JW, Thompson TA (2005) Hydrogeomorphic classification for great Lakes coastal wetlands. J Great Lakes Res 31(Supplement 1):129-146. doi:10.1016/ S0380-1330(05)70294-X

Apan AA, Peterson JA (1998) Probing tropical deforestation: the use of GIS and statistical analysis of georeferenced data. Appl Geogr 18:137-152. doi:10.1016/S0143-6228(98)00004-6

Brinson MM (1993) A hydrogeomorphic classification for wetlands US Army corps of Engineers, Washington DC. http://citeseerx. ist.psu.edu/viewdoc/download?doi=10.1.1.463.3580\&rep= rep1\&type $=$ pdf

Buis E, Veldkamp A (2008) Modelling dynamic water redistribution patterns in arid catchments in the Negev Desert of Israel. Earth Surf Proc Land 33:107-122. doi:10.1002/esp.1531

Burns RB, Burns RA (2009) Logistic regression. In: Business research methods and statistics using SPSS. SAGE Publications
Ltd, pp. 565-588. http://www.uk.sagepub.com/burns/website\% 20material/Chapter\%2024\%20-\%20Logistic\%20regression.pdf

Chirico GB, Western AW, Grayson RB, Blöschl G (2005) On the definition of the flow width for calculating specific catchment area patterns from gridded elevation data. Hydrol Process 19:2539-2556. doi:10.1002/hyp.5730

Cowardin LM, Carter V, Golet FC, LaRoe ET (1979) Classification of wetlands and deep water habitats of the United States. US department of the interior fish and Wildlife service; Office of biological services, Washington, DC

Creed IF, Sanford SE, Beall FD, Molot LA, Dillon PJ (2003) Cryptic wetlands: integrating hidden wetlands in regression models of the export of dissolved organic carbon from forested landscapes. Hydrol Process 17:3629-3648. doi:10.1002/hyp.1357

Curie F, Gaillard S, Ducharne A, Bendjoudi H (2007) Geomorphological methods to characterise wetlands at the scale of the Seine watershed. Sci Total Environ 375:59-68. doi:10.1016/j.scito tenv.2006.12.013

Dai W, Huang Y (2006) Relation of soil organic matter concentration to climate and altitude in zonal soils of China. Catena 65:87-94. doi:10.1016/j.catena.2005.10.006

de Koning GHJ, Veldkamp A, Fresco LO (1998) Land use in Ecuador: a statistical analysis at different aggregation levels. Agric Ecosyst Environ 70:231-247

Delepierre G (1982) Les régions agro-climatiques en relation avec l'intensité de l'erosion du sol. Bulletin Agricole du Rwanda 2:87-95

Dimitriou E, Zacharias I (2010) Identifying microclimatic, hydrologic and land use impacts on a protected wetland area by using statistical models and GIS techniques. Math Comput Model 51:200-205. doi:10.1016/j.mcm.2009.08.009

Fóti S et al (2014) Soil moisture induced changes on fine-scale spatial pattern of soil respiration in a semi-arid sandy grassland. Geoderma 213:245-254. doi:10.1016/j.geoderma.2013.08.009

Galletti CS, Ridder E, Falconer SE, Fall PL (2013) Maxent modeling of ancient and modern agricultural terraces in the Troodos foothills, Cyprus. Appl Geogr 39:46-56. doi:10.1016/j.apgeog. 2012.11.020

Gell P, Mills K, Grundell R (2013) A legacy of climate and catchment change: the real challenge for wetland management. Hydrobiologia 708:133-144. doi:10.1007/s10750-012-1163-4

Grzybowski K (1992) The Quaternary formations and palaeogeomorphology of the Lake Kivu segment of the Central African Rift. Bull Pol Acad Sci Earth Sci 40:279-300

Hansen MK, Brown DJ, Dennison PE, Graves SA, Bricklemyer RS (2009) Inductively mapping expert-derived soil-landscape units within dambo wetland catenae using multispectral and topographic data. Geoderma 150:72-84. doi:10.1016/j.geoderma.2009.01.013

Hengl T, Gruber S, Shrestha DP (2003) Digital terrain analysis in ILWIS. Lecture notes and user guide. ITC, Enschde, p 65

Hijmans RJ, Cameron SE, Parra JL, Jones PG, Jarvis A (2005) Very high resolution interpolated climate surfaces for global land areas. Int J Climatol 25:1965-1978. doi:10.1002/joc.1276

Hogg AR, Todd KW (2007) Automated discrimination of upland and wetland using terrain derivatives. Can J Remote Sens 33:S68S83

Karim F, Kinsey-Henderson A, Wallace J, Arthington AH, Pearson RG (2012) Modelling wetland connectivity during overbank flooding in a tropical floodplain in north Queensland Australia. Hydrol Process 26:2710-2723. doi:10.1002/hyp.8364

Keddy P (2010) Wetland ecology: principles and conservation. Cambridge University Press, Cambridge

Kharkar M, Bowalekar S (2014) Extent of under reporting of adverse drug reactions (ADRs) in India: evaluation using logistic regression analysis (LRA). Model Clin Tr. doi:10.4172/21670870.1000155 
Kok K, Veldkamp A (2001) Evaluating impact of spatial scales on land use pattern analysis in Central America. Agric Ecosyst Environ 85:205-221

Kok K, Veldkamp T (2011) Scale and governance: conceptual considerations and practical implications. Ecol Soc 16(2):23. http://www.ecologyandsociety.org/vol16/iss2/art23/

Large ARG, Petts GE (1996) Historical channel-floodplain dynamics along the River Trent: implications for river rehabilitation. Appl Geogr 16:191-209. doi:10.1016/0143-6228(96)00004-5

Long JA, Nelson TA, Wulder MA (2010) Characterizing forest fragmentation: distinguishing change in composition from configuration. Appl Geogr 30:426-435. doi:10.1016/j.apgeog. 2009.12.002

Melloh RA, Racine CH, Sprecher SW, Greeley NH, Weyrick PB (1999) Comparisons of digital terrain data for wetland inventory on two Alaskan Army bases. Hanover, NH Special report 99-15

Mendoza-Sanchez I, Phanikumar MS, Niu J, Masoner JR, Cozzarelli IM, McGuire JT (2013) Quantifying wetland-aquifer interactions in a humid subtropical climate region: an integrated approach. J Hydrol 498:237-253. doi:10.1016/j.jhydrol.2013.06. 022

Mukashema A, Veldkamp A, Vrieling A (2014) Automated high resolution mapping of coffee in Rwanda using an expert Bayesian network. Int J Appl Earth Obs Geoinf 33:331-340. doi:10.1016/j.jag.2014.05.005

Nagumo N, Sugai T, Kubo S (2013) Late quaternary floodplain development along the Stung Sen River in the Lower Mekong Basin. Cambodia Geomorphol 198:84-95. doi:10.1016/j.geo morph.2013.05.016

Ndayambaje J, Heijman WJM, Mohren GMJ (2012) Household determinants of tree planting on farms in rural Rwanda. Smallscale For 11:477-508

Nzigidahera B (2007) Study of the flora in the Cohoha sub-basin; wetland and biodiversity component of nile transboundary environmental action project/UNOPS

Prioul C, Sirven P (1981) Atlas du Rwanda. Kigali, Paris, Nantes, p 32

Ralph TJ, Hesse PP (2010) Downstream hydrogeomorphic changes along the Macquarie River, southeastern Australia, leading to channel breakdown and floodplain wetlands. Geomorphology 118:48-64. doi:10.1016/j.geomorph.2009.12.007
Ravi RP, Kulasekaran RA (2013) Trends in reproductive tract infections and barriers to seeking treatment among young women: a community based cross sectional study in South India. Am J Epidemiol Infect Dis 1:53-58

REMA (2008) Etablissement d'un inventaire national rapide des marais et élaboration de 5 avant-projets d'arrêtés ministériels relatifs aux marais

Safari B (2012) Trend analysis of the mean annual temperature in Rwanda during the last 52 years. J Environ Prot 3:538-551. doi:10.4236/jep.2012.36065

Schulte L, Veit H, Burjachs F, Julià R (2009) Lütschine fan delta response to climate variability and land use in the Bernese Alps during the last 2400 years. Geomorphology 108:107-121. doi:10.1016/j.geomorph.2007.11.014

Swedesurvey (2010) Project of Rwanda national land use and development master plan, report for production of ortho photo in Rwanda

Temme AJAM, Schoorl JM, Veldkamp A (2006) Algorithm for dealing with depressions in dynamic landscape evolution models. Comput Geosci 32:452-461

Veldkamp A, Fresco LO (1997) Reconstructing land use drivers and their spatial scale dependence for Costa Rica (1973 and 1984). Agric Syst 55:19-43. doi:10.1016/S0308-521X(95)00080-O

Xie Z, Liu Z, Jones JW, Higer AL, Telis PA (2011) Landscape unit based digital elevation model development for the freshwater wetlands within the Arthur C Marshall Loxahatchee National Wildlife Refuge, Southeastern Florida. Appl Geogr 31:401-412. doi:10.1016/j.apgeog.2010.10.003

Yamazaki D, Baugh CA, Bates PD, Kanae S, Alsdorf DE, Oki T (2012) Adjustment of a spaceborne DEM for use in floodplain hydrodynamic modeling. J Hydrol 436-437:81-91

Zhao X, Stein A, Chen X-L (2011) Monitoring the dynamics of wetland inundation by random sets on multi-temporal images. Remote Sens Environ 115:2390-2401. doi:10.1016/j.rse.2011. 05.002

Zhou D, Gong H, Liu Z (2008) Integrated ecological assessment of biophysical wetland habitat in water catchments: linking hydroecological modelling with geo-information techniques. Ecol Model 214:411-420. doi:10.1016/j.ecolmodel.2008.03.014 